\title{
Caveolin-1 Expression in Schwann Cells
}

DANIEL D. MIKOL,* HOYLOND L. HONG, HSIN-LIN CHENG, AND EVA L. FELDMAN

Department of Neurol ogy, University of Michigan, Ann Arbor, Michigan

KEY WORDS caveolae; cholesterol; differentiation; myelin; nerve

\begin{abstract}
Caveolae are non-clathrin-coated invaginations of the plasma membrane, which are present in most cell types. An integral component of caveolae is the caveolin family of related proteins, which not only forms the structural framework of caveolae, but also likely subserves its functional roles, including regulation of signal transduction and cellular transport, in particular, cholesterol trafficking. Although caveolae have been identified ultrastructurally in the peripheral nervous system (PNS), caveolin expression has not previously been studied. To date, three caveolin genes have been reported. Here, we show for the first time that caveolin-1 is expressed by Schwann cells (SC) as well as several SC-derived cell lines. Caveolin-1 is enriched in the buoyant, detergent-insoluble membranes of rat sciatic nerve (SN) and SC, a hallmark of the caveolar compartment. Caveolin-1 exists as both soluble and insoluble forms in rat SN and SC, and localizes to SC cytoplasm and abaxonal myelin. SC caveolin-1 decreases after axotomy, when SC revert to a premyelinating phenotype. We speculate that caveolin-1 may regulate signal transduction and/or cholesterol transport in myelinating SC. GLI A 27:39-52, 1999. @ 1999 Wiley-Liss, Inc.
\end{abstract}

\section{INTRODUCTION}

Caveolae are plasma membrane microdomains that can invaginate to form $50-100 \mathrm{~nm}$ vesicles, and are enriched in cholesterol, glycosphingolipids, a variety of signaling molecules, and the caveolins, a family of 18-24 kD proteins. There are four known structurally homologous caveolin isoforms transcribed from three separate genes (Glenney and Soppet, 1992; Scherer P et al., 1996; Tang et al., 1996). Caveolin-1 consists of $21 \mathrm{kD}$ and $24 \mathrm{kD}$ isoforms derived from alternate translational start sites, and it was the first characterized member of the caveolin family (Rothberg et al., 1992). It is present in most cell types, but is especially abundant in epithelial cells, fibroblasts, typel pneumocytes, adipocytes, and smooth muscle cells (Lisanti et al., 1994a, 1995a; Severs, 1988). Caveolin-1 is a membrane protein that forms part of the cytoplasmic coat of caveol ae (Lisanti et al., 1993), interacting with itself to form homo-oligomers (Fra et al., 1995b). Caveolin-2 (20 kD) has not been extensively studied, but has a similar distribution to caveolin-1 (Scherer $\mathrm{P}$ et al., 1996), with which it can form hetero-oligomeric complexes (Scheiffele et al., 1998), whereas caveolin-3 (18 kD) is considered muscle-specific (Tang et al., 1996).
A number of functions are proposed for caveolae: (1) the uptake of small mol ecules such as folate into cells, a process known as potocytosis (Anderson et al., 1992); (2) the transcytosis of molecules such as low density lipoprotein across cells (Simionescu, 1983); (3) polarized trafficking of proteins, especially in epithelial cells (Simons and Wandinger-Ness, 1990); (4) cholesterol transport (Murata et al., 1995); and (5) regulation of signal transduction (Anderson, 1993; Lisanti et al., 1994b, 1995c; Wu et al., 1997). A "caveolae signaling hypothesis" proposes that compartmentalization of signaling molecules within caveolae allows for efficient coupling of activated receptors to a number of different effector systems (Lisanti et al., 1994a; Okamoto et al., 1998; Sargiacomo et al., 1993).

By virtue of its ability to self-oligomerize, caveolin may serve a scaffolding role (Sargiacomo et al., 1995).

Grant sponsor: National Institutes of Health; Grant numbers: NS01928, NS36778, NS38849; Grant sponsor: J uvenile Diabetes Foundation; Grant sponsor: American Diabetes Foundation.

*Correspondence to: Dr. Daniel D. Mikol, University of Michigan, Departmen of Neurology, 200 Zina Pitcher Place, 4414 Kresge III, Ann Arbor, MI 48109. E-mail: dmiko@umich.edu

Received 4 December 1998; Accepted 11 February 1999 
Caveolin-1 directly binds cholesterol (Murata et al., 1995) and possi bly glycosphingoli pids (F ra et al., 1995a; Parton, 1994), both of which are abundant in caveolae (Simionescu et al., 1983). The uniqueli pid microenvironment of caveolaeaccounts for theinsolubility of caveoaleassociated molecules in most nonionic detergents and the low density of caveolae relative to other cellular membranes, properties used to isolate caveolin-enriched membranes (CEMs) from a variety of cells and tissues (Lisanti et al., 1995b; Song et al., 1996a). CEMs are thought to be the biochemical counterparts of caveol ae and are thus enriched in a variety of signaling molecules. For example, all of the following are concentrated within caveolae-like membranes: the receptors for insul in (Mastick and Saltiel, 1997), platelet-derived growth factor (Liu et al., 1996), the nerve growth factors p75NTR (Bilderback et al., 1997) and trkB (Wu et al., 1997), basic fibroblast growth factor (Gleizes et al., 1996), epidermal growth factor (Smart et al., 1995), bradykinin $\left(B_{2}\right)$ (Haasemann et al., 1998), and atrial natriuretic peptide (type B) (Doyle et al., 1997). In addition, caveolin-1 binds directly to the epidermal growth factor receptor (Couet et al., 1997; Smart et al., 1995), p75 NTR (Bilderback et al., 1997), and a variety of lipid-modified signaling molecules, such as Ras (Song et al., 1996a), Src-like kinases (Li et al., 1996a), endothelial nitric-oxidesynthase (Shaul et al., 1996) and G-proteins (Li et al., 1995).

Plasma membrane invaginations with the morphologic appearance of caveolae are present in blood vessels (Olsson and Reese, 1971), cells forming theperineurial sheaths of the PNS (Akert et al., 1976; Hall and Williams, 1971; Olsson and Reese, 1971; Reale et al., 1975; Sandri et al., 1977; Waggener et al., 1965), and SC (Mugnaini et al., 1977). However, caveolin expression within SC has not been explored. We have previously reported caveol in immunoreactivity in detergentinsoluble fractions of rat SN (Mikol and Feldman, 1997). Here, we demonstrate that caveolin-1 is expressed by SC and is enriched in a low-density membrane fraction using a detergent-free method to enrich for CE Ms. Caveolin-1 from SN or SC is present in both soluble and membrane-associated forms and localizes toSC cytoplasm and abaxonal myelin. Caveolin-1 immunoreactivity is significantly decreased after axotomy, suggesting that its expression is greatest in differentiated SC.

\section{MATERIALS AND METHODS Materials}

Rat SN and lung were purchased from Pel-Freez (Rogers, AR) for immunoblotting. Adult rat SN was frozen in OCT compound (Ted Pella, Inc., Redding, CA) and sectioned for immunohistochemistry. Adult rat teased SN fibers and transected SN (distal stumps collected 12 days after axotomy) (Scherer $\mathrm{S}$ et al., 1995), fixed in $4 \%$ paraformaldehyde, were generously pro- vided by Dr. S. Scherer (University of Pennsylvania, Philadelphia, PA). The mouse monoclonal antibody (mAb) (C37120), the affinity-purified rabbit polyclonal antibody (pAb) against caveol in-1, and anti-Fyn rabbit pAb were purchased from Transduction Laboratories (Lexington, KY). The anti-S100 mAb (S-2532) was purchased from Sigma (St. Louis, MO), while the anti-myelin basic protein (MBP) mAb was obtained from Boehringer Mannheim (Indianapolis, IN). Dr. J . Archelos (Max Planck Institute for Psychiatry, München, Germany) kindly provided the anti- $P_{0} m A b$. Anti-PMP-22 and anti-myelin associated glycoprotein (MAG) rabbit pAbs were generous gifts from Dr. E. Shooter (Stanford University, Stanford, CA) and Dr. J . Salzer (New York University, New York, NY), respectively.

\section{Cell Culture}

In general, all cells were grown at $37^{\circ} \mathrm{C}$ in a humidified atmosphere with $10 \% \mathrm{CO}_{2}$. For analysis by SDSpolyacrylamide gel electrophoresis (PAGE), cells were grown to $\sim 80 \%$ confluency and collected for protein quantification. SH-SY5Y and SHEP human neuroblastoma cells and NIE-115 rat neuroblastoma cells were kindly provided by Drs. S. Fisher, V. Castle, and S. O'Shea, respectively, all at the University of Michigan. PC12 cells (rat pheochromocytoma origin) and N2a mouseneuroblastoma cells were purchased from American Type Culture Collections (Manassas, VA). PC12 cells were grown in RPMI 1640 medium with $5 \%$ fetal bovine serum (FBS) and 10\% horse serum, while N2a cells were grown in minimal essential media plus $10 \%$ FBS and supplemented with $1 \%$ nonessential amino acids (Gibco BRL Products, Gaithersburg, MD). SHSY5Y, SHEP and NIE-115 cells were cultured in Dulbecco's modified Eagl e's media (DME M) plus 10\% F BS. The SV-40 immortalized SC line MT4H1 (Peden et al., 1989), a gift from Dr. G. Tennekoon (University of Pennsylvania), was grown in DMEM containing $10 \%$ FBS, $100 \mu \mathrm{M} \mathrm{ZnSO}_{4}$, and $100 \mu \mathrm{g} / \mathrm{ml} \mathrm{G} 418$, while S16, S16Y, and S42, all generated by repetitive passaging of rat SC in the laboratory of Dr. R. Quarles (National Institutes of Health, Bethesda, MD; Sasagasako et al., 1996), were grown in DMEM, 10\% FBS, and $100 \mu \mathrm{g} / \mathrm{ml}$ gentamycin. The SV-40 immortalized oligodendroglial cell lines N19 and N20 (Verity et al., 1993), supplied by Dr. A. Campagnoni (University of California at LoS Angeles, Los Angeles, CA), were grown in Ham's F-12 media plus 10\% Nu-serum (Collaborative-Becton Dickinson, Bedford, MA).

SC obtained from SN of 3-day-old Sprague Dawley rats (Harlan-Sprague Dawl ey, I ndianapol is, I N; Brockes et al., 1979) were cultured on poly-L-lysine coated plates and maintained in standard growth medium consisting of DMEM with $10 \% \mathrm{FBS}$, supplemented with $6 \mathrm{mM}$ L-glutamine, $2 \mu \mathrm{M}$ forskolin and $10 \mu \mathrm{g} / \mathrm{ml}$ pituitary extract (Sigma; Brockes et al., 1979; Porter et 
al., 1986). Cells were passaged upon confluency and used for 4 passages. To test the effects of raised intracellular CAMP levels on caveolin-1 expression, SC were grown for 24-72 $\mathrm{h}$ in defined medium (Cheng et al., 1998) with or without $2 \mu \mathrm{M}$ forskolin. Rat dorsal root ganglion cells isolated from E15 Sprague-Dawley rat pups (Russell et al., 1998) and SC were co-cultured on poly-L-lysine coated coverslips for $48 \mathrm{~h}$ in defined medium plus $10 \mathrm{nM}$ insulin like growth factor-I, which has been shown to promote myelination (Cheng et al., 1998).

\section{Membrane F ractionation}

Rat SN or SC were homogenized at $4^{\circ} \mathrm{C}$ in phosphate buffered saline (PBS) plus $1 \mathrm{mM}$ phenylmethylsulfonylfluoride and protease inhibitor cocktail (BoehringerMannhei m), then centrifuged at 200,000 g for $1 \mathrm{~h}$. After separation, equal aliquots of the supernatant and pellet were analyzed by Western blotting. CEMs were prepared from rat SN or SC by discontinuous density gradient centrifugation in the presence or absence of detergent, using established procedures (see bel ow). All steps were carried out at $4^{\circ} \mathrm{C}$. Briefly, $\sim 10-15$ adult SN or two $150 \mathrm{~mm}$ plates of cultured SC were utilized per centrifuge tube, whether the detergent-based or detergent-free protocol was followed.

For preparation of low density, Triton-insol uble membranes, the method of Lisanti (Lisanti et al., 1995b) was used with minor modifications. The sample was homogenized in $3 \mathrm{ml} 25 \mathrm{mM}$ 2-(N-morpholino)ethane sulfonic acid (pH 6.5) plus $0.15 \mathrm{M} \mathrm{NaCl}$ (MBS) containing $1 \%$ Triton-X-100, $1 \mathrm{mM}$ phenylmethylsulfonylfluoride and protease inhibitor cocktail. After 8-10 strokes with a Dounce homogenizer, $3 \mathrm{ml}$ of lysate was combined 1:1 with $80 \%$ sucrose (in MBS) and placed at the bottom of a centrifuge tube. A 5\%-15\%-25\% step gradient (2 ml each in MBS, without detergent) was layered above, and the sample was centrifuged at 200,000 $\mathrm{g}$ for $20 \mathrm{~h}$ in a SW 41 rotor (Beckman Instruments, Palo Alto, CA). Twelve $1 \mathrm{ml}$ fractions were collected (top to bottom) and equal aliquots of these fractions plus the initial homogenate and pellet were analyzed by SDS-PAGE.

Detergent-free extractions were performed essentially as described (Song et al., 1996a). Tissue or cells were homogenized in $0.5 \mathrm{M}$ sodium carbonate ( $\mathrm{pH}$ 11.0) using a Dounce homogenizer, followed by sonication (three 20 sec bursts). The sample was then combined $1: 1$ with $80 \%$ sucrose (in MBS) and overlaid with a step gradient of $5 \%-15 \%-25 \%$ sucrose (containing MBS plus $0.25 \mathrm{M}$ sodium carbonate). Centrifugation and collection of aliquots were carried out as above for the detergent-based method.

\section{Electrophoresis and Western B lotting Analysis}

Protein samples were quantified using a Protein Assay kit (Bio-Rad Laboratories, Richmond, CA). Poly- peptides and pre-stained molecular mass standards (Amersham Life Science, Arlington Heights, IL) were separated by SDS-PAGE ( $8 \%, 10 \%$, or $12 \%$ acrylamide) using the method of Laemmli (Laemmli, 1970) and electrically transferred to nitrocellulose as previously described (Mikol and Stefansson, 1988). To minimize non-specific binding of antibodies, nitrocel lul ose sheets were then blocked overnight in $5 \%$ nonfat dry milk or $4 \%$ bovine serum al bumin (each in Tris-buffered saline plus $0.05 \%$ Tween 20 ), for polyclonal and monoclonal antibody immunoblotting, respectively. Antibodies were diluted in the blocking solution to minimize nonspecific reactions. Nitrocellulose sheets were immunoblotted with mAb $(1: 2,000)$ or affinity-purified pAb $(1: 4,000)$ against caveolin- 1, pAb against Fyn $(1: 2,000)$, MAG $(1: 10,000)$ or PMP-22 $(1: 2,000)$, or mAb against $\operatorname{MBP}(1: 2,000)$, followed by peroxidase-conjugated secondary antibodies (1:2,500; Santa Cruz Biotechnology, Santa Cruz, CA) diluted in the appropriate blocking solution. Both monoclonal and polyclonal anti-caveolin antibodies were used to ensure specific binding to caveolin-1. Immunoblots were visualized using enhanced chemiluminescence reagents. To verify specific binding of antibody to caveolin-1, positive (lung lysate) and negative (SY5Y cell lysate) controls were immunoblotted along with the SN or SC samples, and parallel immunoblots were incubated in the absence of primary antibody (conjugate control) for each antibody.

\section{Immunohistochemistry and I mmunocytochemistry}

Frozen sections of rat $\mathrm{SN}$ were brought to room temperature prior to processing. Adult SN and transected SN sections, teased fibers and SC/dorsal root ganglion neuron co-cultures grown on poly-L-lysine-coated coverslips were either fixed in $4 \%$ paraformal dehyde (in PBS) for 15 min or immunostained without fixation. Samples were permeabilized with either $0.1 \%$ Triton $\mathrm{X}-100$ (in PBS) for $20 \mathrm{~min}$ or acetone at $-2^{\circ} \mathrm{C}$ for 10 min. After a $30 \mathrm{~min}$ incubation in blocking solution (2\% nonfat dry milk plus $0.1 \%$ Triton X-100 in PBS) to minimize nonspecific binding of antibodies, samples were incubated with primary antibody in blocking solution for $24 \mathrm{~h}$ at $4^{\circ} \mathrm{C}$. Antibodies against caveol in-1, $\mathrm{S} 100$ and $\mathrm{P}_{0}$ were all used at 1:500. After washing with PBS, a 6 h incubation with secondary antisera (1:100) at room temperature followed, using either $\mathrm{Cy}-3$ conjugated anti-rabbit or FITC-conjugated anti-mouse antibodies (J ackson Immunoresearch, Westgrove, PA) in blocking solution. In addition, conjugate controls (no primary antibody) were done in parallel to demonstrate that immunoreactivity was due to binding of primary antibody. Slides were coverslipped and viewed by fluorescence microscopy using a Leitz fluorovert microscope (W. Nuhsbaum Inc., McH enry, IL). 


\section{RESULTS \\ Caveolin-1 Expression in SC and SC Derived Lines}

We analyzed caveolin-1 expression in a number of different neural cell lines derived from neuroblastoma (N2a, SH-SY5Y, SHEP, NIE-115), pheochromocytoma (PC12), oligodendrocytes (N19,N20), or SC (MT4H1, S16, S16Y, S42) by immunoblotting cell lysates with an affinity-purified anti-caveolin-1 pAb (Fig. 1A). The apparent molecular weight of caveolin-1 is $\sim 24$ kD (size markers not shown). Three exposures of the same immunoblot are presented (with intentional overexposure of some lanes at $30 \mathrm{~s}$ and $8 \mathrm{~min}$ ) to emphasize relative caveol in-1 levels. Of the neural cell lines tested, SC derived cell lines express the greatest levels of caveol in-1. Within a class of comparable cell lines, the cell line with the more differentiated phenotype, S16 compared to S16Y and S42 (Sasagasako et al., 1996) and N20 compared to N19 (Verity et al., 1993), expresses relatively more caveol in-1. SHEP and SH-SY 5Y cells are derived from the same parental neuroblastoma (Biedler et al., 1988). SHEP cells, which are more differentiated and have been described as having a SC phenotype, express abundant caveolin-1, whereas the less differentiated SH-SY5Y cells, which have a neuroblastic phenotype, express no caveol in-1.

We next sought to identify caveolin-1 in rat SC. Figure 1B shows that caveolin-1 is present both in a rat SN homogenate, which contains a variety of cell types, and in a pure lysate from cultured rat SC. A rat lung lysate, which contains abundant caveolin-1, serves as a positive control. In all of our experiments caveolin-1 from SN and cultured SC has a molecular weight of $\sim 24$ kD and co-migrates with caveol in-1 from rat lung.

\section{CE Ms from SC and SN}

Two establ ished protocols were used to isolate CEMs from rat SN and cultured SC. The first protocol utilizes detergent, while the second does not. In each case, thin flocculent bands are visible with the naked eye at the $5 \%-15 \%$ and $15 \%-25 \%$ sucrose interfaces. Figure $2 \mathrm{~A}$ demonstrates that caveolin-1 from rat SN detergent preparations is enriched in fractions 2 through 5, near the $5 \%-15 \%$ and $15 \%-25 \%$ sucrose interfaces, which is consistent with the buoyant characteristics of caveolin from other tissues (Scherer P et al., 1996; Song et al., 1996a,b). However, a considerable portion of caveolin-1 remains in the soluble $40 \%$ sucrose layer (fractions 7-12).

Because compact myelin membranes have a light density (N orton and Poduslo, 1973) comparable to that of CEMs, the above SN fractions were immunoblotted with antibodies against several myelin proteins, including MAG, MBP, $\mathrm{P}_{0}$, and PMP-22 (Fig. $2 A$ ), in order to determine the usefulness of CEM preparations when applied to nervous tissue. There is some variability in the staining patterns, presumably reflecting differen-

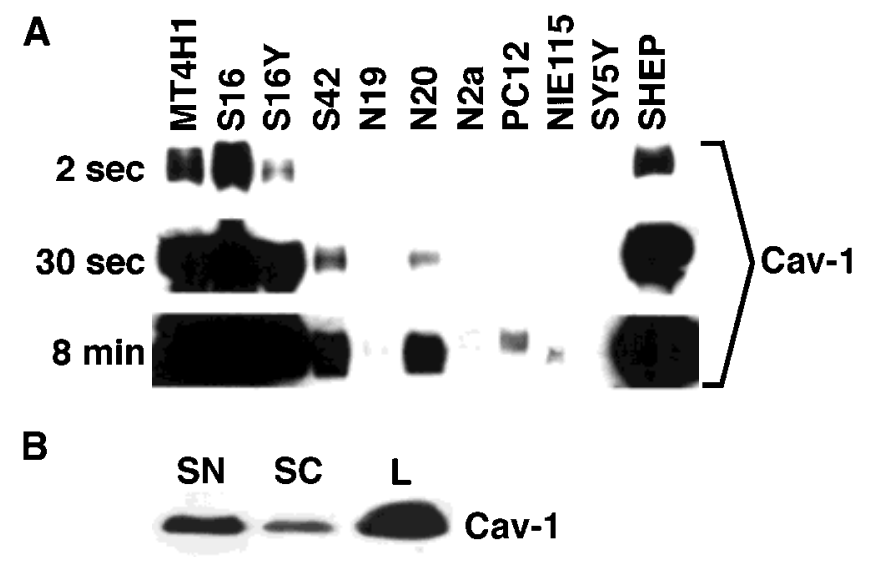

Fig. 1. Caveolin-1 expression in SC derived cell lines and SC. A: Cell lysates $(50 \mu \mathrm{g})$ from a number of neural cell lines were immunoblotted with anti-caveolin-1 (Cav-1) pAb. Three exposures (increasing exposure time from top to bottom) are shown in order to illustrate the relative levels of caveol in-1 expression. The SC lines (MT4H 1, S16 and S16Y, and S42) express caveolin-1, although there is some variability in the amounts expressed. The SC-like cell line SHEP expresses abundant caveolin-1, whereas SH-SY 5Y cells, derived from the same neuroblastoma, have no detectable caveolin-1. One oligodendrocyte cell line (N20) expresses caveolin-1, while N19 and several neuronallike cell lines (PC12, N2a, NIE-115, SH-SY5Y) have minimal to no detectable caveolin-1. B: Rat SN $(20 \mu \mathrm{g})$, SC $(50 \mu \mathrm{g})$ and lung $(\mathrm{L})(0.2$ $\mu \mathrm{g})$ were immunoblotted with anti-caveolin-1 pAb. The results demonstrate the presence of caveolin-1 in all lysates. The apparent mol ecular weight of caveolin-1 is $\sim 24 \mathrm{kD}$ (not shown).

tial detergent-solubilities of the myelin proteins. MAG is largely present in the $40 \%$ sucrose layer (fractions 7-12), i.e., the original lysate layer, but is also present to a lesser extent in fractions 3 and 4 . In contrast, MBP and $\mathrm{P}_{0}$ are present in most fractions. While these results show that caveolin-1 and the compact myelin protein PMP-22 are enriched in similar fractions, this is likely due to the similar buoyant characteristics of CEMs and myelin membranes. We do not detect significant caveolin-1 in compact myel in membranes isolated by the method of Norton and Poduslo (1973; data not shown). Thus, density-based methods used to enrich for CEMs from nervous tissue are limited by the comparable densities of CEMs and myelin membranes, which results in their co-purification.

Detergent-free preparation of CE Ms from SN and SC lysates again reveals enrichment of caveolin-1 within fractions around the $5 \%-15 \%$ and $15 \% / 25 \%$ sucrose interfaces (Fig. 2B). These SC cultures are not myelinating, implying that the CEMs here are equivalent to typical caveolae-like membranes (Song et al., 1996a). Once again, caveolin-1 is detected in the lower sucrose fractions from both SN and SC, which indicates that a fraction of caveolin-1 is soluble in buffer al one. Figure 2C illustrates how SN and SC caveol in-1 partitions into soluble and membrane-associated forms.

The nonreceptor tyrosine kinase Fyn is concentrated within caveolae (Lisanti et al., 1995a). Caveolin-1 interacts directly with Fyn and other Src-like kinases, inhibiting their activity ( $\mathrm{Li}$ et al., 1996a). Because Fyn mediates integrin downstream signaling and anchoragedependent growth in fibroblasts (Wary et al., 1998) and 

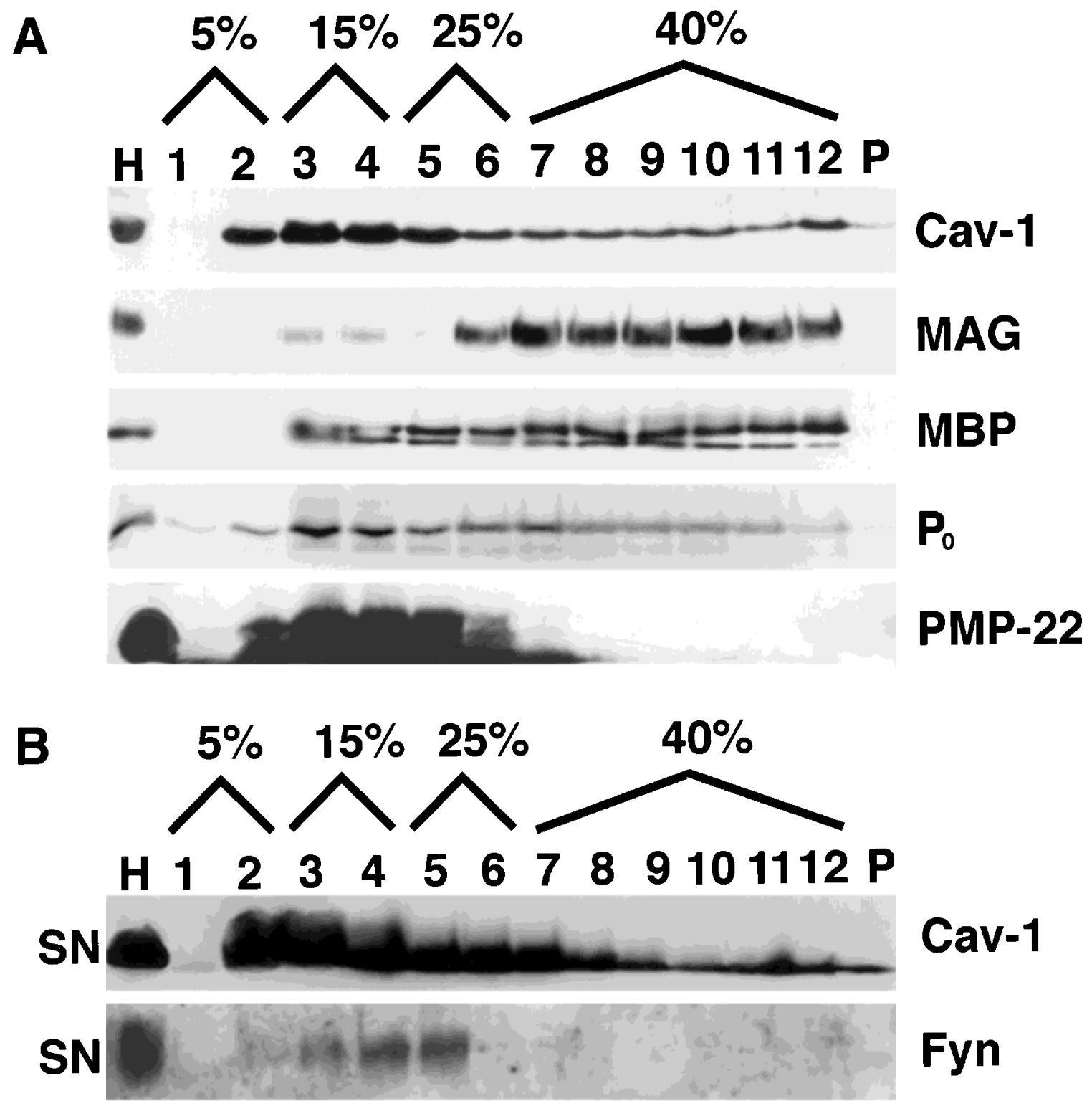

Fyn

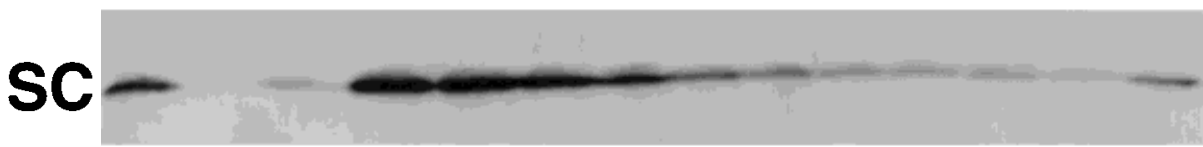

Cav-1

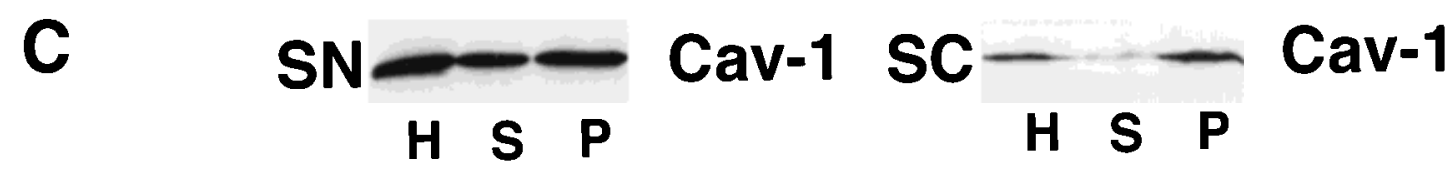

Fig. 2. CEMs from rat SN. A: Rat SN was homogenized and subjected to discontinuous sucrose gradient centrifugation in the presence of Triton X-100. Equal aliquots of the initial homogenate $(\mathrm{H})$, insoluble pellet $(P)$, or fractions 1 through 12 (top to bottom) were analyzed by SDS-PAGE, followed by immunoblotting. Caveolin-1 (Cav-1) is enriched in low density membranes (fractions 2 through 5), although it is also detected in the higher density sucrose and pellet fractions. For comparison, the same fractions were immunoblotted with antibodies against several myelin proteins: MAG, MBP, $P_{0}$, and PMP-22. B: Rat SN or SC was homogenized and subjected to sucrose gradient centrifugation in the absence of detergent. Equal aliquots of the initial homogenate $(H)$, insoluble pellet $(P)$, or fractions 1 through
12 were analyzed by SDS-PAGE, followed by immunoblotting with anti-caveolin-1 or anti-Fyn pAb (Fyn). Again, caveol in-1 is enriched in the low density membranes (fractions 2 through 5), although small amounts are again detected in the higher density sucrose and pellet fractions. Fyn is enriched in similar buoyant membrane fractions from SN. C: Rat SN or SC was homogenized in PBS and centrifuged at high speed in order to identify soluble and membrane-associated forms of caveolin-1. Equal volume aliquots of the initial homogenate $(\mathrm{H})$, or $200,000 \mathrm{~g}$ supernatant $(\mathrm{S})$, or pellet $(\mathrm{P})$ from rat SN or SC were separated by SDS-PAGE and immunoblotted with anti-caveolin-1 $\mathrm{pAb}$. A soluble form of caveolin-1 is detected in both SN and SC, although it appears to be more prevalent in the SN sample. 
some of the downstream signaling events necessary for myelination in the central nervous system (Umemori et al., 1994), it is possible that Fyn plays a role in PNS myel ination. We were unable to detect $F y n$ in cultured SC (data not shown). However, using either method to prepare CEMs from SN, Fyn is highly concentrated within the buoyant fractions that are also enriched in caveol in-1. Figure 2B demonstrates an anti-Fyn immunoblot of a detergent-free CEM preparation from SN .

\section{Caveolin-1 Localization in Rat SN}

Vesicles with the appearance of caveol ae were identified ultrastructurally in peripheral nerve two decades ago. Most of these studies described such vesicles in perineurium and blood vessels (Akert et al., 1976; Hall and Williams, 1971; Olsson and Reese, 1971; Reale et al., 1975; Sandri et al., 1977; Waggener et al., 1965), although a single report described them in SC (Mugnaini et al., 1977). Using an affinity-purified anticaveol in-1 pAb to stain SN, SC and abaxonal myelin are strongly immunostained, with additional staining of the perineurium and blood vessels (Figs. 3-6). Cross sections reveal caveol in-1 immunoreactivity of SC cytoplasm, while the abaxonal localization is most apparent on longitudinal sections. Cytoplasmic caveol in-1 immunoreactivity overlaps with the S100 staining pattern (Fig. 3). Doubleimmunostaining with antibodies against caveol in- 1 and $\mathrm{P}_{0}$ demonstrates that there is no caveolin-1 staining of compact myelin (data not shown). Caveolin-1 immunostaining of adult SN teased fibers localizes to SC cytoplasm (including paranodes) and abaxonal myelin, but in addition reveals a stippled appearance (Fig. 4). Such punctate caveolin-1 immunoreactivity suggests the distribution of caveolae (Rothberg et al., 1992). S100 immunostaining of teased fibers shows a similar staining of SC cytoplasm, but without the stippled pattern seen in the case of caveolin-1. Immunofluorescent staining of cultured SC (Fig. 5A) and SC/dorsal root ganglion co-cultures (Fig. 5B), using the same caveol in-1 pAb, intensely labels SC, whereas neurons and their axons do not visibly stain. The staining pattern is punctate over the entirety of the cells, along stress fibers, and at the cell margins. The SC membrane is strongly caveolin-1 immunoreactive where it contacts axons.

We have shown here that caveolin-1 is expressed in PNS myelin. We questioned whether caveol in-1 expression might be affected by in vivo axonal cues, such as nerve transection, which down-regulates myelin genes (Mirsky and J essen, 1990; Scherer et al., 1993), or el evated intracellular CAMP, which induces expression of myelin genes in vitro (J essen et al., 1991; Lemkeand Chao, 1988). We chose to look at SC caveol in-1 levels 12 days after nerve transection, as myel in protein expression declines considerably by this time (Scherer S et al., 1995). Figure 6 A,C shows that SC caveolin-1 expression decreases significantly after axotomy; perineurium and blood vessels retain intense caveolin-1 immunoreactiv- ity, which serves as an internal control. P0 is detected 12 days after axotomy in myelin debris (Fig. 6B,D). SC persist and are S100 positive (not shown).

We al so questioned whether caveolin-1 expression by SC was affected in vitro by forskolin, which raises intracellular CAMP, mimicking in part axonal contact and thereby inducing expression of myelin genes such as $\mathrm{P}_{0}$ (Lemke and Chao, 1988). We conducted several experiments exposing SC to $2 \mu \mathrm{M}$ forskolin, with incubation varying between 24 and $72 \mathrm{~h}$. In every case, $\mathrm{P}_{0}$ expression increases in the presence of $2 \mu \mathrm{M}$ forskolin, whereas caveolin- 1 levels are unaltered. Figure $6 \mathrm{E}$ shows the effects of forskolin treatment (for $24 \mathrm{~h}$ ) on caveolin-1 and P0 expression by cultured SC. Thus, caveolin-1 expression is associated with a myelinating phenotype but does not appear to be coordinately linked with the expression of myelin genes.

\section{DISCUSSION}

The caveolins are increasingly being implicated in such diverse biological processes as signal transduction, cellular transport, differentiation, and apoptosis (for review see Okamoto et al., 1998). However, caveolin has been little studied in the nervous system. We questioned whether caveolin-1 was expressed in SC and their differentiated organelle, myelin. Here, we have identified caveolin-1 in a rat SN homogenate, which contains a number of different cell types, in SC derived cell lines, and in a pure SC lysate (Fig. 1).

Of the neural cell lines tested, the SC derived cell lines (MT4H1, S16, S16Y, S42) express the greatest levels of caveolin-1, and cell lines with more differentiated phenotypes express relatively more caveolin-1 (Biedler et al., 1988; Sasagasako et al., 1996; Verity et al., 1993; Fig. 1A). Although they were both derived from a single human neuroblastoma (Biedler et al., 1988), the SH-SY5Y and SHEP cell lines show differential caveolin-1 expression. SHEP cells, which have some characteristics of SC, tend to be relatively slow growing, have a finite life-span in vitro, are anchorage and serum dependent, and do not typically form tumors in nude mice. In contrast, SH-SY5Y cells have neuroblastic characteristics, divide more readily, are anchorage and serum independent, and readily form tumors in nude mice. SHEP cells express abundant caveolin-1 whereas SH-SY 5Y cells have no detectable caveol in-1. Of course, caution must be used in interpreting these results, as protein expression in cell lines is not necessarily representative of protein expression in primary cells in vitro or in vivo. Nonetheless, these results are consistent with previous findings that associate caveolin expression with a differentiated cellular state ( $\mathrm{F}$ an et al., 1983; Scherer P et al., 1995; Song et al., 1996b).

The caveolins are most abundantly expressed in terminally differentiated cells such as muscle cells, endothelial cells, and adipocytes. For example, caveolin-1 levels increase as much as 25-fold when NIH3T3 fibroblasts differentiate into adipocytes (Fan et al., 
A

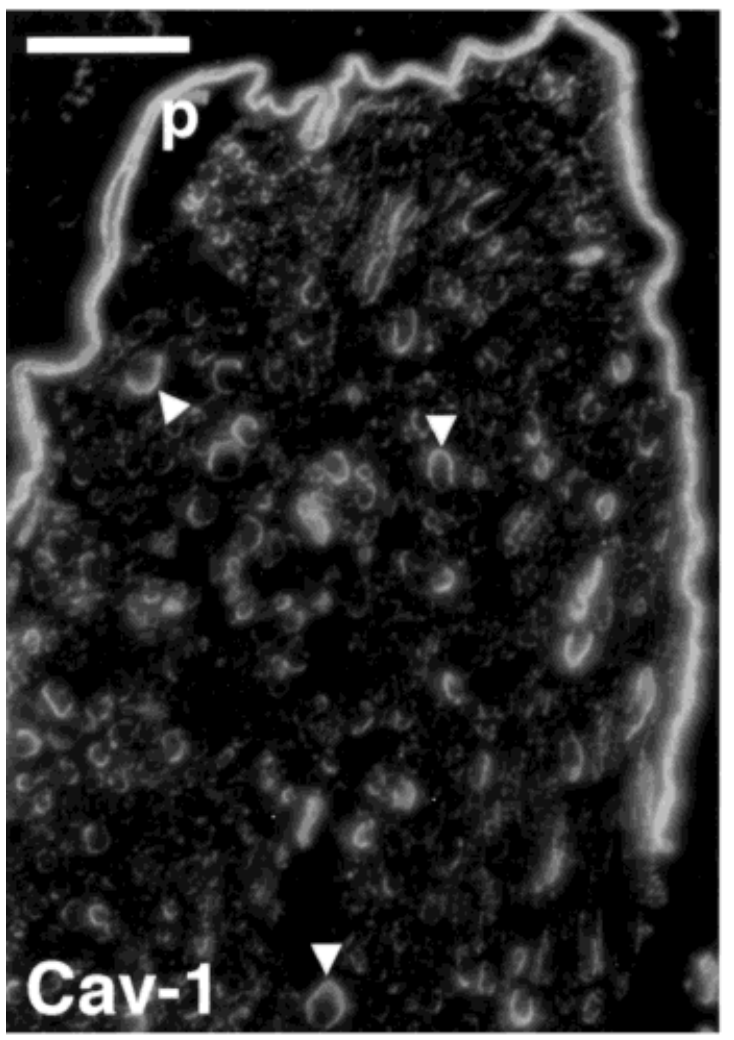

B

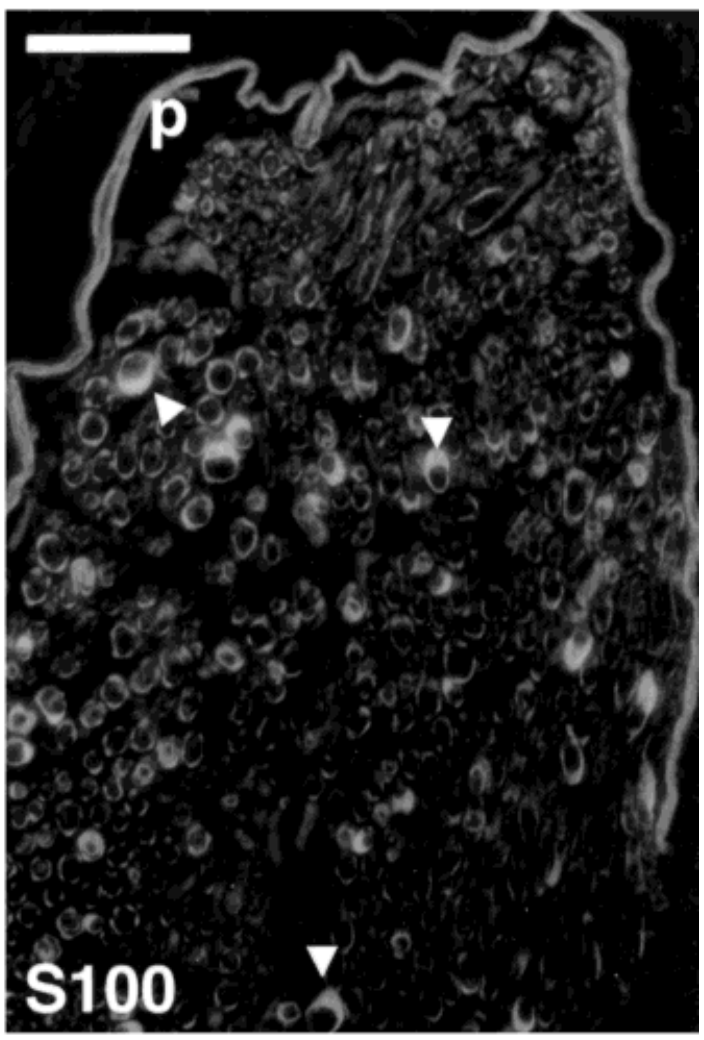

C

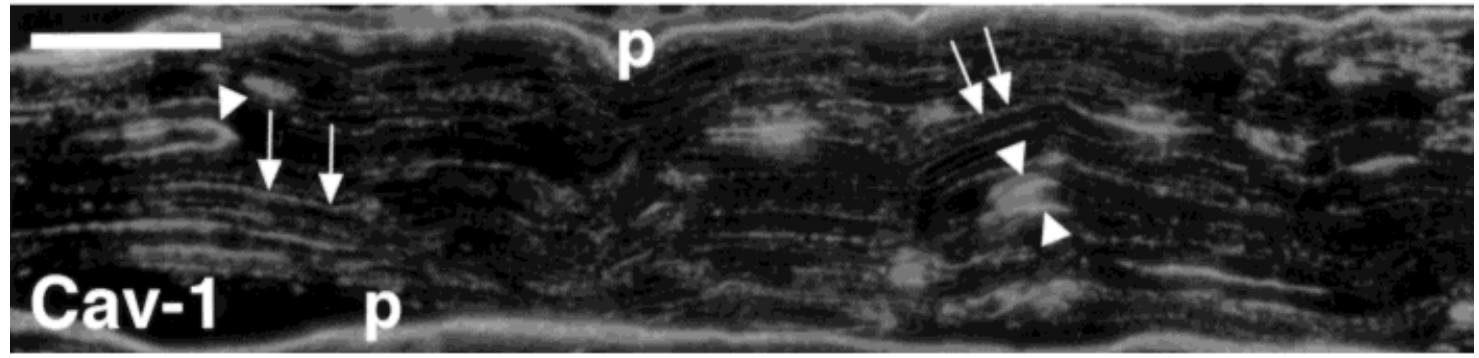

D

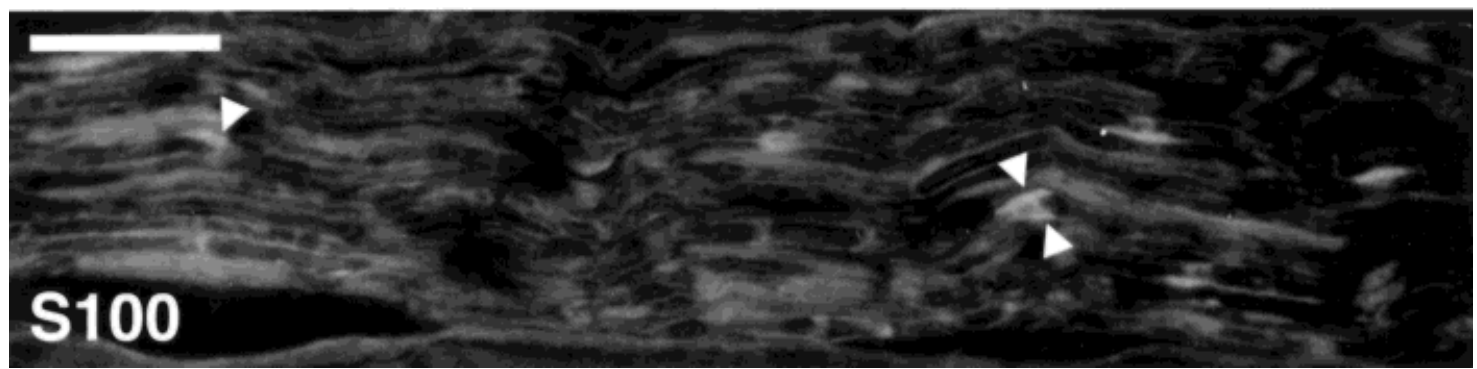

Fig. 3. Caveolin-1 localization in rat SN. Rat SN sections were permeabilized with $0.1 \%$ Triton $\mathrm{X}-100$ and double immunostained with pAb against caveolin-1 (Cav-1) $(\mathbf{A}, \mathbf{C})$ and mAb against $\mathrm{S} 100$ $(\mathbf{B}, \mathbf{D})$. The cross sections $(A, B)$ reveal crescent-shaped caveolin-1 immunoreactivity of SC cytoplasm (arrowheads). Longitudinal sections $(C, D)$ demonstrate caveol in-1 staining in a linear fashion that is consistent with immunoreactivity of abaxonal myelin (arrows) as well as SC cytoplasm (arrowheads). Perineurium (p) is also immunoreactive for caveolin-1. The pattern of S100 immunostaining of SC cytoplasm (arrowheads) overlaps with that of caveolin-1. Scale bar = $20 \mu \mathrm{M}$. 


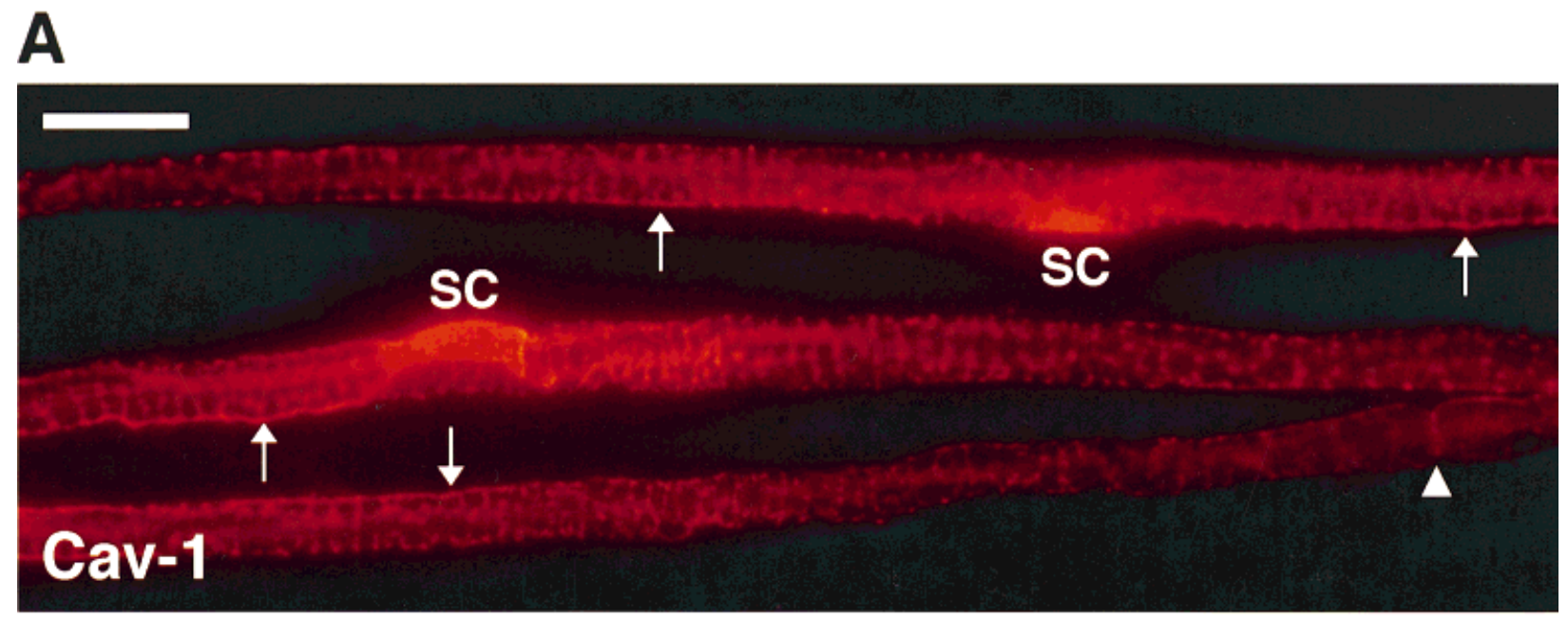

\section{B}

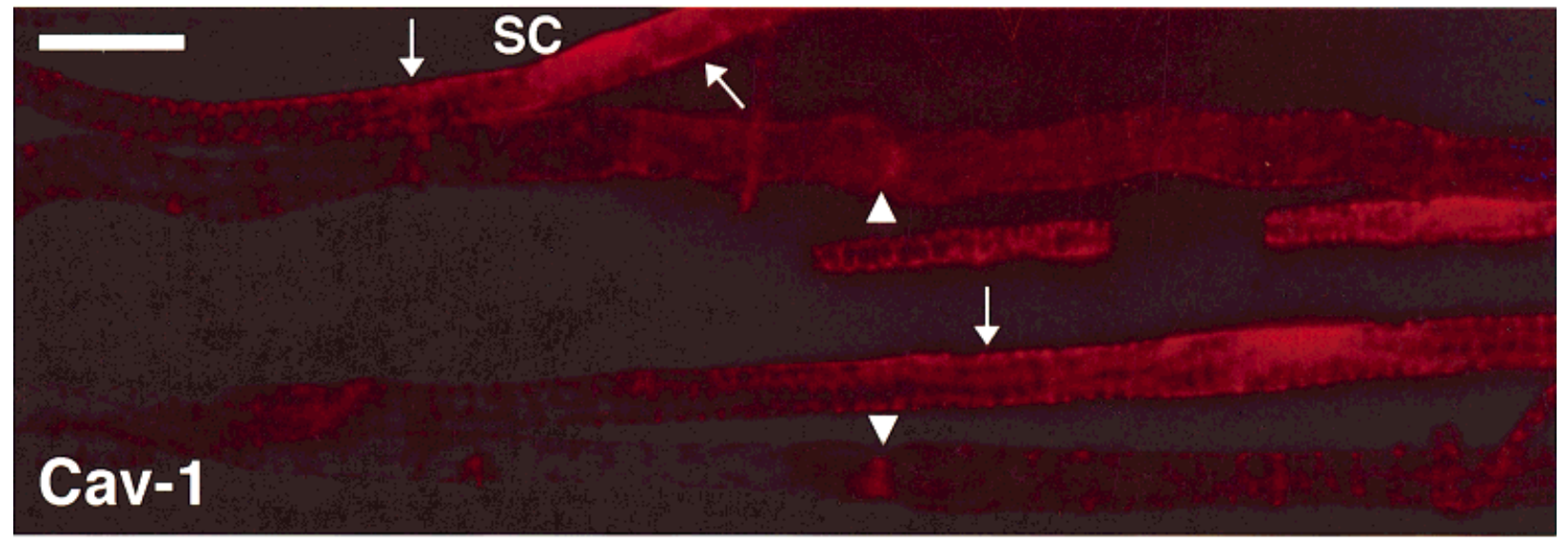

C

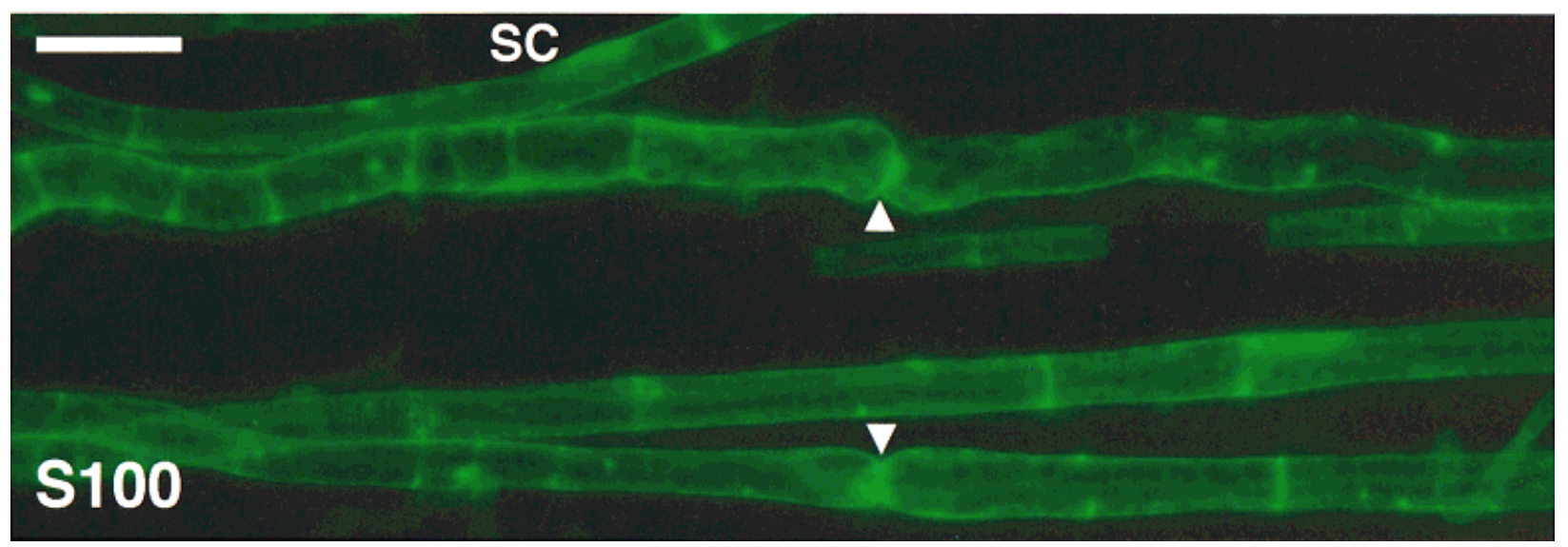

Fig. 4. Caveolin-1 immunostaining of rat SN teased fibers. Rat SN teased fibers were immunostained with pAb against caveol in-1 (Cav-1) $(\mathbf{A}, \mathbf{B})$ or mAb against S100 (C). Double immunostaining of the same fibers with caveolin-1 and S100 is illustrated in (B) and (C). Caveolin-1 is strongly localized in the outer myelin membrane (arrows) and SC

cytoplasm (SC). Caveolin-1 is also found at the paranodes (arrowheads). Caveol in-1 immunoreactivity has a stippled appearance, most apparent in (A), which was permeabilized with cold acetone. (B) and (C) were permeabilized with $0.1 \%$ Triton X-100. Caveolin-1 and S100 are both detected in SC cytoplasm. Scale bar $=10 \mu \mathrm{M}$. 


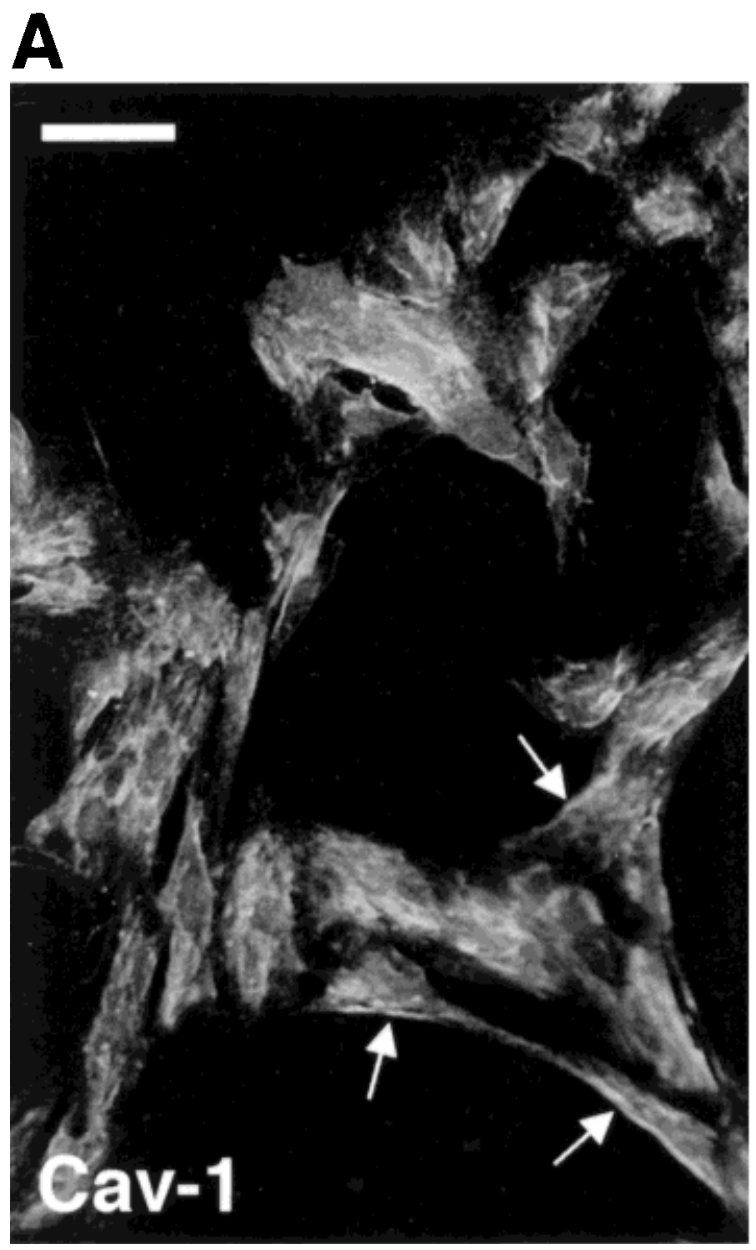

Fig. 5. Caveolin-1 immunostaining of SC in vitro. Rat SC (A) or co-cultures of SC/dorsal root ganglion neurons harvested $48 \mathrm{~h}$ after plating in the presence of insulin like growth factor-I (B) were immunostained with anti-caveolin-1 (Cav-1) pAb, after first permeabil-

1983; Scherer $\mathrm{P}$ et al., 1995), and caveolin-3 expression increases substantially during differentiation of C2C12 myoblasts into myotubes (Song et al., 1996b). In contrast, cellular transformation results in decreased levels of caveolin and caveolae (Engelman et al., 1997; Koleske et al., 1995). Caveolin expression in transformed cells leads to suppression of the transformed phenotype (Engelman et al., 1998b; Lee et al., 1998), with loss of anchorage independent growth (Engelman et al., 1997). The mechanisms for the effects of caveolins on growth control are being el ucidated. It appears that caveolins function largely as negative regulators of signal transduction, e.g., by suppressing MAP kinase activity (Engelman et al., 1997, 1998a) and signaling through the Neu receptor (Engel man et al., 1998b), the epidermal growth factor receptor, and protein kinase $C$ (Couet et al., 1997). However, caveolin may stimulate other signal transducing molecules, such as the insulin receptor (Yamamoto et al., 1998). Thus, regulated caveolin expression by SC may in part determine their responsiveness to growth factors, and ultimately, their phenotype.

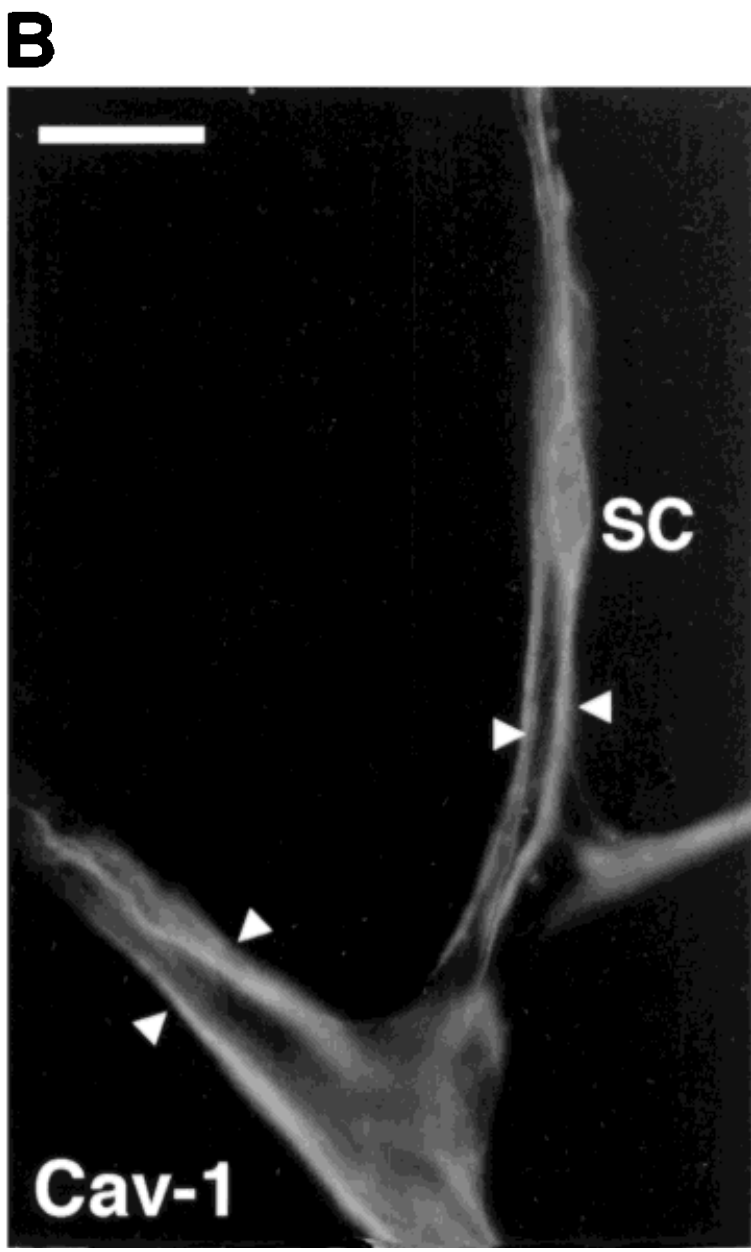

izing cells with $0.1 \%$ Triton X-100. Strong SC staining is evident, especially at cell margins (A, arrows) and where SC membranes abut axons (B, arrowheads), whereas axons do not appreciably stain. In (A), scale bar $=20 \mu \mathrm{M}$; in (B), scale bar $=10 \mu \mathrm{M}$.

Clearly, caveolin is an essential structural protein of caveolae, and its expression is sufficient to drive the formation of caveolaelike vesicles. Cells that contain abundant caveolae, such as adipocytes, endothelial cells, smooth muscle cells, and fibroblasts also express the highest levels of caveol in (Glenney, 1992; Lisanti et al., 1994b). Furthermore, within a given cell type expressing caveolin-1, the degree of caveolin-1 expression correlates with the number of caveolae ( $F$ an et al., 1983; Kol eske et al., 1995; Scherer P et al., 1994; 1996). Recombinant expression of caveolin in cell lines without detectable caveolin, or identifiable caveolae, results in caveolin enrichment within caveolae-like membranes and the de novo formation of caveolae (F ra et al., 1995b; Scherer $P$ et al., 1995). Thus, the presence of a caveolin in SC likely drives the formation of caveolae, and we ther efore aniticipated that caveol in-1 would be present in CEMs from SN and SC (Fig. 2).

CEMs can be prepared on the basis of their low density and detergent-insolubility. They share many of the features of caveolae (Lisanti et al., 1995b; Song et al., 1996a), including enrichment in cholesterol, as well 
A

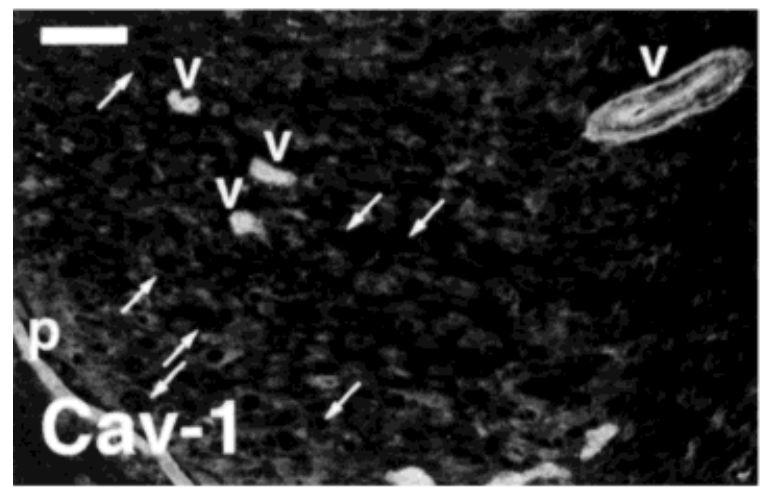

C

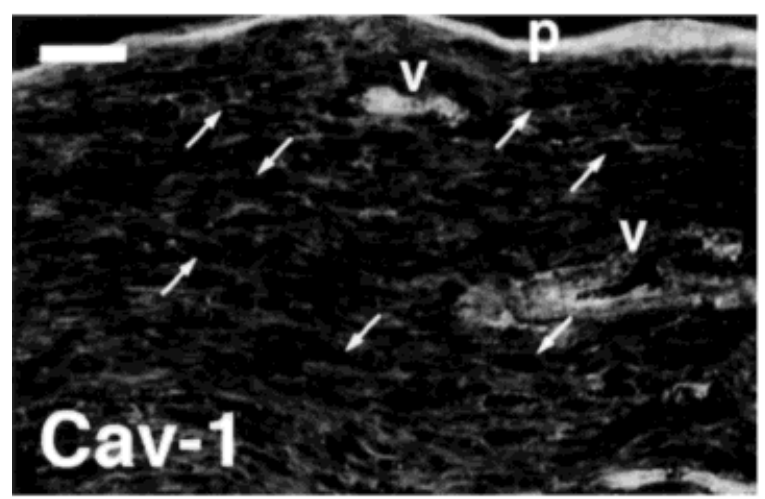

B

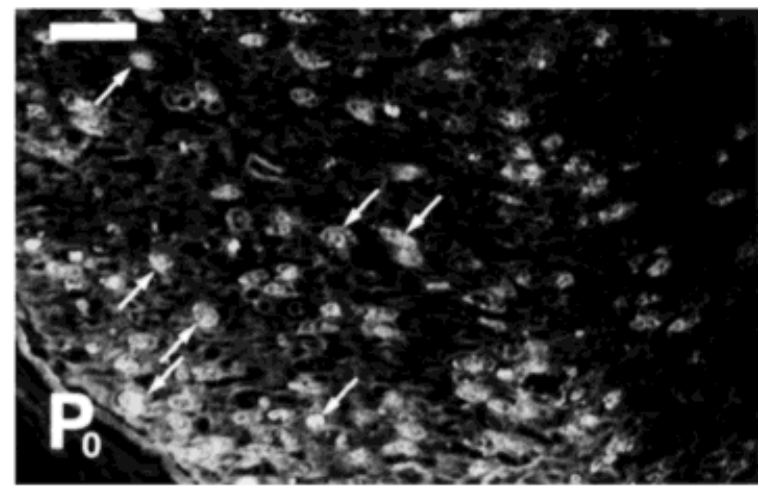

D

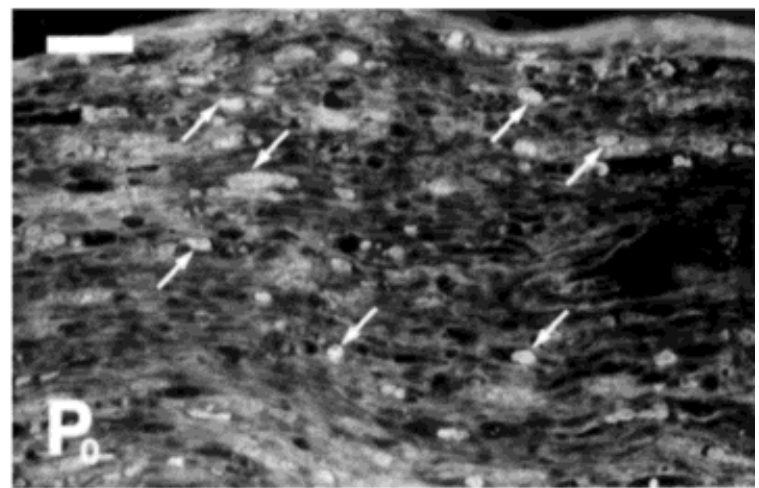

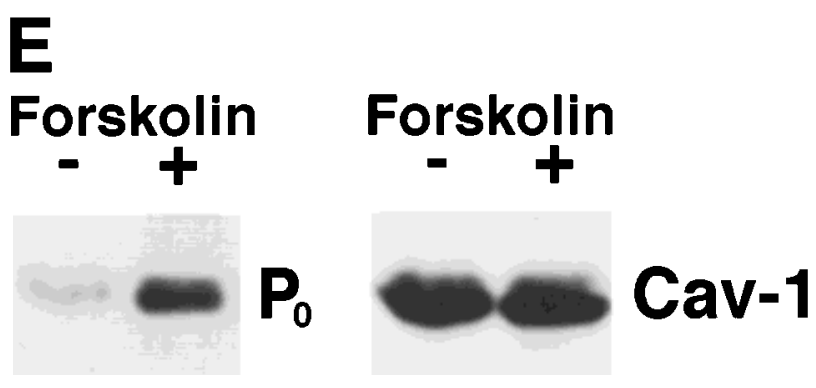

Fig. 6. Axonal influences on caveolin-1 expression. Rat SN collected 12 days after nerve transection were permeabilized with $0.1 \%$ Triton $\mathrm{X}-100$ and double immunostained with pAb against caveol in-1 (Cav-1) $(\mathbf{A}, \mathbf{C})$ and $P_{0}(\mathbf{B}, \mathbf{D})$. Cross sections are shown in $(A)$ and $(B)$, while longitudinal sections are shown in (C) and (D). SC caveolin-1 expression is reduced significantly (compare to Fig. 3), while perineurial (p) and blood vessel (v) caveolin-1 staining remain intense. $P_{0}$ is detected

as glycosphingolipids and a variety of signal-transducing components (Lisanti et al., 1994b; Montesano et al., 1982; Parton, 1994; Sargiacomo et al., 1993). Because detergent-based methods to prepare CEMs are susceptible to potential artifacts, such as apparent enrichment in glycosylphosphatidylinositol-anchored proteins (Schnitzer et al., 1995), weal so used an established detergent-free protocol to prepare CEMs from rat SN and SC. Using either method, caveolin-1 is enriched in in myelin debris (arrows); areas of $\mathrm{P}_{0}$ immunoreactivity are indicated in panels (A-D, arrows). Scale bars $=20 \mu \mathrm{M}$. E: SC were cultured in serum-free defined medium with $(+)$ or without $(-) 2 \mu \mathrm{M}$ forskol in for $24 \mathrm{~h}$, and cell lysates were immunoblotted with anti- $\mathrm{P}_{0} \mathrm{mAb}$ or anti-caveolin-1 pAb. $P_{0}$ increases with forskolin treatment whereas caveolin-1 expression is unaffected.

a buoyant membrane fraction (fractions 2 through 5 ) of SN and SC (Fig. 2A,B). The Src-like kinase Fyn, which is known to be enriched in caveolae (Lisanti et al., 1995a), is concentrated within overlapping fractions from SN. While SN preparations are complicated by the presence of compact myelin, which has a comparable light density, nonmyelinating SC cultures also show enrichment of caveolin-1 in buoyant fractions, i.e., CEMs. 
I mmunohistochemically, caveolin-1 is detected in SC cytoplasm and abaxonal myelin (Figs. 3 and 4), which may correspond to soluble and insoluble forms of caveolin-1, respectively (Fig. 2C). The cytoplasmic localization of caveolin-1 is readily apparent when compared to the similar staining pattern of S100. Adult SN teased fibers and cultured SC immunostained for caveolin-1 demonstrate a stippled appearance of immunoreactivity (Figs. 4 and 5), which has been noted in other cell types and likely correlates with the distribution of caveolae (Cameron et al., 1997; Rothberg et al., 1992; Scherer, P. et al., 1995). We have previously shown that $\mathrm{SC}$ align along axons by $48 \mathrm{~h}$ in SC/dorsal root ganglion neuron co-cultures treated with insulin like growth factor-I (Cheng et al., 1998). Here, we find that after 48 $\mathrm{h}$ of co-culture, the SC membrane is strongly caveolin-1 immunoreactive where it abuts axons (Fig. 5B), which could reflect compartmentalized signal transduction at the intial stage of myelination. Although Galbiati et al . (1998) have recently identified caveolin expression in the cell bodies and growth cones of dorsal root ganglion neurons, we did not observecaveol in-1 immunostaining of axons.

SC phenotype is controlled by downstream signaling effects of the extracellular matrix (Bunge et al., 1986; Eldridge et al., 1989), cell-cell adhesion events (Owens and Bunge, 1989; Wood et al., 1990), and growth factors (Brockes et al., 1980; Cheng et al., 1998; Davis and Stroobant, 1990; Goodearl et al., 1993; Hansson et al., 1986; Krasnoselsky et al., 1994; Ridley et al., 1989). When premyelinating SC contact axons during development, they align on and ensheath axons (Webster, 1993). Myelin formation follows attainment of a one-toone ratio between SC and large axons, and is accompanied by $\mathrm{SC}$ expression of myel in genes such as $\mathrm{P}_{0}, \mathrm{MBP}$, and MAG (J essen et al., 1991) and suppression of SC proliferation (J essen and Mirsky, 1991). After nerve transection, with loss of axonal signals, SC revert to a premyelinating phenotype and no longer express myelin genes (Mirsky and J essen, 1990; Scherer et al., 1993, 1996). Figures 6A-D shows that SC caveolin-1 expression decreases substantially after nerve transection. Caveolin-1 staining of blood vessels and perineurium remains intense, while SC staining declines (see Fig. 3 for comparison). Our preliminary results show that caveolin-1 is also devel opmentally regulated, concordant with the onset of myelination (not shown). In non-neural cells, caveolin-1 expression is associated with differentiation in sensescent cells, as well as with cell death in cells that are rapidly dividing (Engelman et al., 1997; Wary et al., 1996). Caveolin-1 might play an analagous role regarding the fate of developing SC, which either cease prol iferation and begin to differentiate in response to axonal signals or undergo cell death (Grinspan et al., 1996; J essen et al., 1994; Nakao et al., 1997; Stewart et al., 1996; Syroid et al ., 1996).

Recently, caveolin-1 has been shown to mediate anchorage dependent growth in fibroblasts by serving as a membrane adaptor protein, linking integrins to Fyn (Wary et al., 1998). Fyn is concentrated within caveolar membranes (Lisanti et al., 1995a) and likely binds caveolin directly (Li et al., 1996a). Although Fyn has not been extensively studied in the PNS, it appears to be involved in the signaling events that occur during the early stages of myelination in the central nervous system (Umemori et al., 1994). Thus, increased caveolin-1 expression in differentiated cells may reflect the effects of the extracellular matrix on growth arrest and differentiation. Extrapolation of these results into SC allows one to speculate that myelination in the PNS might require signaling pathways that involve the extracellular matrix, caveolin-1 and Fyn. Caveolin-1's abaxonal localization is consistent with its possible role mediating integrin signaling.

The effects of axonal contact upon SC can be partially mi micked in vitro by el evating CAMP levels (Lemkeand Chao, 1988). That is, SC expression of myelin genes such as $P_{0}, M B P$, and MAG increases upon CAMP elevation. We did not find any difference in SC expression of caveolin-1 after treatment with $2 \mu \mathrm{M}$ forskolin for 24-72 $h$, whereas $P_{0}$ expression increased under this condition. Figure $6 \mathrm{E}$ shows the effects of forskol in on SC expression of $\mathrm{P}_{0}$ and caveolin- 1 after $24 \mathrm{~h}$. These data suggest that caveolin-1 expression is regulated by other factors and is not directly linked to the transcription of myelin genes.

There is growing evidence that sterol levels control caveolin-1 expression at the level of transcription (Bist et al., 1997; Fu et al., 1998). At the same time, caveolin-1 may itsel f regulate cholesterol efflux in fibroblasts, with the expression of caveol in-1 varying in response to cellular cholesterol content (Fiel ding and Fielding,1995, 1997b; Fielding et al., 1997a). Interestingly, hydroxymethyl glutaryl-coenzyme A reductase, the rate-limiting enzyme in cholesterol biosynthesis, is upregulated in parallel with myelination, yet this enzyme is also unaffected by elevated CAMP levels (Fu et al., 1998). Rather, it is regulated primarily by the intracellular sterol concentration (Fielding et al., 1997a; Fu et al., 1998; Holthuizen et al., 1990). Although caveolin-1 is thought to be a membrane protein, a considerable portion of caveol in-1 from SN or SC is soluble in buffer al one (Fig. 2C). These results are interesting in light of the recent findings by Uittenbogaard et al. (1998), who have identified a soluble heat-shock protein-caveolinchaperone complex in NIH 3 T3 cells that transports newly synthesized cholesterol en route to caveolar membranes by a vesicle-independent mechanism. Soluble caveolin-1 in SN and SC might be similarly associated with newly synthesized cholesterol. We detect a larger fraction of soluble caveol in-1 in SN than in cultured SC (Fig. 2C), perhaps reflecting the greater need for cholesterol synthesis in myel in forming SC.

It is unknown whether caveolin-1 mediates cholesterol transport in SC, whose cholesterol is entirely endogenous, but caveolin-1 expression could facilitate chol esterol trafficking and ulti matel y myel in synthesis. Given that cholesterol binds caveolin-1 (Murata et al., 1995), accounts for roughly $25 \%$ of myel in lipids (Dewille and Horrocks, 1992), is entirely derived from locally 
synthesized sources in peripheral nerve ( urevics and Morell, 1994; J urevics et al., 1998), and is essential for the proper structure and function of caveolae (Hailstones et al., 1998; Li et al., 1996b; Rothberg et al., 1990; 1992), it is plausible that caveolin-1 might regulate cholesterol trafficking during myelination and remyelination.

In summary, caveolin-1 is expressed by SC. Caveolin-1 exists in sol uble and membrane associated forms, and is localized to SC cytoplasm and abaxonal myelin membranes. Caveolin-1 is expressed in myelinating SC but decreases after axotomy, when SC revert to a premyelinating phenotype. We postulate that caveolin-1 may regulate signal transduction and/or cholesterol transport in myelin forming SC.

\section{ACKNOWLEDGMENTS}

Thanks to Drs. G. Tennekoon, A. Campagnoni, R. Quarles, J . Salzer, and E. Shooter for supplying materials. Dr. S. Scherer generously contributed teased fibers and invaluable discussion. We thank Ms. J. Boldt and Mr. J . Beals for additional assistance.

This work was supported by NIH NS01928 (D.D.M.), NIH NS36778, NIH NS38849, the J uvenile Diabetes Foundation, and the American Diabetes Foundation (E.L.F.).

\section{REFERENCES}

Akert KC, Sandri C, Weibel ER, Peper K, Moor H. 1976. The fine structure of the perineural endothelium. Cell Tissue Res 165:281295.

Anderson RGW. 1993. Caveolae: where incoming and outgoing messengers meet. Proc Natl Acad Sci USA 90:10909-10913.

Anderson RGW, Kamen BA, Rothberg KG, Lacey SW. 1992. Potocytosis: sequestration and transport of small molecules by caveolae. Science 255:410-411.

Biedler J L, Spengler BA, Tien-ding C, Ross RA. 1988. Transdifferentiation of human neuroblastoma cells results in coordinate loss of neuronal and malignant properties. Adv N euroblastoma Res 2:265276.

Bilderback TR, Grigsby RJ, Dobrowsky RT. 1997. Association of p75NTR with caveolin and localization of neurotrophin-induced sphingomyelin hydrolysis to caveolae. J Biol Chem 272:1092210927.

Bist A, Fielding PE, Fielding CJ . 1997. Two sterol regulatory elementlike sequences mediate up-regulation of caveol in gene transcription in response to low density lipoprotein free cholesterol. Proc Natl Acad Sci 94:10693-10698.

Brockes J P, Fields KL, Raff MC. 1979. Studies on cultured rat Schwann cells. I. Establishment of purified populations from cultures of peripheral nerve. Brain Res 165:105-118.

Brockes J P, Lemke GE, Balzer DR. 1980. Purification and preliminary characterization of a glial growth factor from bovine pituitary.J Biol Chem 255:8374-8377.

Bunge RP, Bunge MB, Eldridge CF. 1986. Linkage between axonal ensheathment and basal lamina production by schwann cells. Annu Rev Neurosci 9:305-328.

Cameron PL, Ruffin J W, Bollag R, Rasmussen H, Cameron RS. 1997. I dentification of caveolin and caveolin-related proteins in the brain. J Neurosci 17:9520-9535.

Cheng H-L, Russell JW, Feldman EL. 1999. Insulin-like growth factor-I promotes Schwann cell motility. Glia (in press).

Couet J, Sargiacomo M, Lisanti MP. 1997. Interaction of a receptor tyrosine kinase, EGF-R, with caveolins. J Biol Chem 272:3042930438.
Davis J B, Stroobant P. 1990. Platelet-derived growth factors and fibroblast growth factors are mitogens for rat Schwann cells. J Cell Biol 110:1353-1360.

Dewille J W, Horrocks LA. 1992. Synthesis and turnover of myelin phospholipids and cholesterol. In: Martenson RE, editor. Myelin: biology and chemistry. Boca Raton: CRC Press. p 213-234.

Doyle DD, Ambler SK, U pshaw-Earley J , Bastawrous A, Goings GE, Page E. 1997. Type $B$ atrial natriuretic peptide receptor in cardiac myocyte caveolae. Circulation Res 81:86-91.

Eldridge CF, Bunge MB, Bunge RP. 1989. Differentiation of axonrelated Schwann cells in vitro: II. Control of myelin formation by basal Iamina.J Neurosci 9:625-638.

Engelman J A, Wyk off CC, Yasuhara S, Song KS, Okamoto T, Lisanti MP. 1997. Recombinant expression of caveolin-1 in oncogenically transformed cells abrogates anchorage-independent growth. J Biol Chem 272:16374-16381.

Engelman J A, Chu C, Lin A, J o H, Ikezu T, Okamoto T, Kohtz DS, Lisanti MP. 1998a. Caveolin-mediated regulation of signaling along the p42/44 MAP kinase cascade in vivo. FEBS Lett 428:205-211.

Engelman J A, Lee RJ , Karnezis A, Bearss DJ , Webster M, Siegel $P$, Muller WJ , Windle JJ, Pestell RG, Lisanti MP. 1998b. Reciprocal regulation of neu tyrosine kinase activity and caveolin-1 protein expression in vitro and in vivo. J Biol Chem 273:20448-20455

Fan J Y, Carpentier J -L, Van Obberghen E, Grunfeld C, Gorden P, Orci L. 1983. Morphological changes of the 3T3-L1 fibroblast plasma membrane upon differentiation to the adipocyte form. J Cell Sci 61:219-230.

Fielding CJ , Fielding PE. 1997b. I ntracellular cholesterol transport. J Lipid Res 38:1503-1521.

Fielding CJ , Bist A, Fielding PE. 1997a. Caveolin mRNA levels are up-regulated by free cholesterol and down-regulated by oxysterols in fibroblast monolayers. Proc Natl Acad Sci USA 94:3753-3758.

Fielding PE, Fielding CJ . 1995. Plasma membrane caveolae mediate the efflux of cellular free chol esterol. Biochemistry 34:14288-14292.

Fra AM, Masserini M, Palestini P, Sonnino S, Simons K. 1995a. A photo-reactive derivative of gangl ioside GM 1 specifically cross-links VIP21-caveolin on the cell surface. FEBS Lett 375:11-14.

Fra AM, Williamson E, Simons K, Parton RG. 1995b. De novo formation of caveolae in lymphocytes by expression of VIP21caveol in. Proc Natl Acad Sci USA 92:8655-8659.

Fu Q, Goodrum J F, Hayes C, Hostettler J D, Toews AD, Morell P. 1998. Control of cholesterol biosynthesis in Schwann cells. J Neurochem 71:549-555.

Gal biati F, Volonte D, Gil O, Zanazzi G, Salzer J L, Sargiacomo M, Scherer PE, Engelman J A, Schlegel A, Parenti M, Okamoto T, Lisanti MP. 1998. Expression of caveolin- 1 and -2 in differentiating PC12 cells and dorsal root ganglion neurons: caveolin-2 is upregulated in response to cell injury. Proc Natl Acad Sci USA 95:10257-10262

Gleizes PE, Noaillac-Depeyre J, Dupont MA, Gas N. 1996. Basic fibroblast growth factor (FGF-2) is addressed to caveolae after binding to the plasma membrane of BHK cells. Eur J Cell Biol 71:144-153.

Glenney J R. 1992. The sequence of human caveolin reveals identity with VIP21, a component of transport vesicles. FEBS Lett 314:4548.

Glenney J R, Soppet D. 1992. Sequence and expression of caveolin, a protein component of caveolae plasma membrane domains phosphorylated on tyrosine in Rous sarcoma virus-transformed fibroblasts. Proc Natl Acad Sci USA 89:10517-10521.

Goodearl ADJ , Davis J B, Mistry K, Minghetti L, Otsu M, Waterfield MD, Stroobant P. 1993. Purification of multiple forms of glial growth factor. J Biol Chem 268:18095-18102.

Grinspan J B, Marchionni MA, Reeves M, Coulaloglou M, Scherer SS. 1996. Axonal interactions regulate Schwann cell apoptosis in developing peripheral nerve: neuregulin receptors and the rol e of neuregulins. J Neurosci 16:6107-6118.

Haasemann M, Cartaud J , Muller-Esterl W, Dunia I. 1998. Agonistinduced redistribution of bradykinin B2 receptor in caveolae. J Cell Sci 111:917-928.

Hailstones D, Sleer LS, Parton RG, Stanley KK. 1998. Regulation of caveolin and caveolae by cholesterol in MDCK cells. J Lipid Res 39:369-379.

Hall SM, Williams PL. 1971. The distribution of el ectron-densetracers in peripheral nervefibres. J Cell Sci 8:541-555.

Hansson HA, Dahlin LB, Danielsen N, Fryklund L, Nachemson AK, Polleryd P, Rozell B, Skottner A, Stemme S, Lundborg, G. 1986. Evidence indicating trophic importance of IGF-I in regenerating peripheral nerves. Acta Physiol Scand 126:609-614.

Holthuizen P, vanderLee FM, I kejiri K, Yamamoto M, Sussenbach I S 1990. Identification and initial characterization of a fourth leader 
exon and promoter of the human IGF-II gene. Biochim Biophys Acta 1087:341-343.

J essen KR, Mirsky R. 1991. Schwann cell precursors and their development. Glia 4:185-194.

J essen KR, Mirsky R, Morgan L. 1991. Role of cyclic AMP and proliferation controls in Schwann cell differentiation. Ann. NY Acad Sci 633:78-89.

J essen KR, Brennan A, Morgan L, Mirsky R, Kent A, Hashimoto Y, Gavrilovic J . 1994. The Schwann cell precursor and its fate: a study of cell death and differentiation during gliogenesis in rat embryonic nerves. Neuron 12:509-527.

J urevics HA, Morell P. 1994. Sources of cholesterol for kidney and nerve during devel opment. J Lipid Res 35:112-120.

J urevics H, Bouldin TW, Toews AD, Morell P. 1998. Regenerating sciatic nerve does not utilize circulating chol esterol. Neurochem Res 23:401-406.

Koleske AJ , Baltimore D, Lisanti MP. 1995. Reduction of caveolin and caveolae in oncogenically transformed cells. Proc Natl Acad Sci USA 92:1381-1385.

Krasnoselsky A, Massay MJ, DeFrances MC, Michalopoulos G, Zarneger R, Ratner N. 1994. Hepatocyte growth factor is a mitogen for Schwann cells and is present in neurofibromas. J Neurosci 14:72847290.

Laemmli UK. 1970. Cleavage of structural proteins during the assembly of the head of bacteriophage T4. Nature 227:680-685.

Lee SW, Reimer CL, Oh P, Campbell DB, Schnitzer J E. 1998. Tumor cell growth inhibition by caveolin re-expression in human breast cancer cells. Oncogene 16:1391-1397.

Lemke G, Chao M. 1988. Axons regulate Schwann cell expression of the major myelin and NGF receptor genes. Development 102:499504.

Li S, Okamoto T, Chun M, Sargiacomo M, Casanova J E, Hansen SH, Nishimoto I, Lisanti MP. 1995. Evidence for a regulated interaction between heterotrimeric G proteins and caveolin. I Biol Chem 270:15693-15701.

Li S, Couet J , Lisanti MP. 1996a. Src tyrosine kinases, Ga subunits, and $\mathrm{H}$-Ras share a common membrane-anchored scaffolding protein, caveolin.J Biol Chem 271:29182-29190.

Li S, Song KS, Lisanti MP. 1996b. Expression and characterization of recombinant caveolin. J Biol Chem 271:568-573.

Lisanti MP, Tang ZL, Sargiacomo M. 1993. Caveolin forms a heterool igomeric protein complex that interacts with an apical GPI-linked protein: implications for the biogenesis of caveolae. J Cell Biol 123:595-604.

Lisanti MP, Scherer PE, Tang Z-L, Sargiacomo M. 1994a. Caveolae, caveol in, and caveol in-rich membrane domains: a signalling hypothesis. Trends Cell Biol 4:231-235.

Lisanti MP, Scherer PE, Vicugiriene J , Tang Z-L, Hermanowski M, Vosatka A, Tu Y-H, Cook RF, Sargiacomo M. 1994b. Characterization of caveol in-rich membrane domains isol ated from an endothelialrich source: implications for human disease. J Cell Biol 126:111126.

Lisanti MP, Scherer PE, Tang, Z-L, Kubler E, KoleskeAJ , Sargiacomo M. 1995a. Caveol ae and human disease: functional roles in transcytosis, potocytosis, signalling and cell polarity. Semin Dev Biol 6:47-58

Lisanti MP, Tang Z-L, Scherer PE, Sargiacomo M. 1995b. Caveolae purification and glycosylphosphatidylinositol-linked protein sorting in polarized epithelia. Methods Enzymol 250:655-668.

Lisanti MP, Tang Z, Scherer PE, Kubler E, KoleskeAJ , Sargiacomo M. 1995c. Caveolae, transmembranesignalling and cellular transformation. Mol Membr Biol 12:121-124.

Liu P, Ying Y, Ko Y-G, Anderson RGW. 1996. Localization of plateletderived growth factor-stimulated phosphorylation cascade to caveolae. J Biol Chem 271:10299-10303.

Mastick CC, Saltiel AR. 1997. Insulin-stimulated tyrosine phosphoryIation of caveolin is specific for the differentiated adipocyte phenotype in 3T3-L 1 cells. J Biol Chem 272:20706-20714.

Mikol DD, Feldman EL. 1997. The oligodendrocyte-myelin glycoprotein is present in a subcompartment of myelin. Neurology Suppl 48:37.

Mikol DD, Stefansson K. 1988. A phosphatidylinositol-linked peanut agglutinin-binding glycoprotein in central nervous system myelin and oligodendrocytes. J Cell Biol 106:1273-1279.

Mirsky R, J essen KR. 1990. Schwann cell development and the regulation of myelination. Semin Neurosci 2:423-435.

Montesano R, Roth J , Robert A, Orci L. 1982. Non-coated membrane invaginations are involved in binding and internalization of cholera and tetanus toxins. Nature 296:651-653.

Mugnaini E, Osen KK, Schnapp B, Friedrich VL. 1977. Distribution of Schwann cell cytoplasm and plasmalemmal vesicles (caveolae) in peripheral myelin sheaths. An electron microscopic study with thin sections and freeze-fracturing. J Neurocytol 6:647-668.
Murata M, Peranen J , Schreiner R, Wieland F, Kurzchalia TV, Simons K. 1995. VIP21/caveolin is a cholesterol-binding protein. Proc Natl Acad Sci USA 92:10339-10343.

Nakao J , Shinoda J , Nakai Y, Murase S, Uyemura K. 1997. Apoptosis regulates the number of Schwann cells at the premyelinating stage. J Neurochem 68:1853-1862.

Norton WT, Poduslo SE. 1973, Myelination in rat brain: method of myelin isolation. J Neurochem 21:749-757.

Okamoto T, Schlegel A, Scherer PE, Lisanti MP. 1998. Caveolins, a family of scaffolding proteins for organizing "preassembled signaling complexes" at the plasma membrane. J Biol Chem 273:54195422.

Olsson Y, ReeseTS. 1971. Permeability of vasa nervosum and perineurium in mouse sciatic nerve studied by fluorescence and electron microscopy. J Neuropathol Exp Neurol 30:105-119.

Owens GC, Bunge RP. 1989. Evidence for an early role for myelinassociated glycoprotein in the process of myelination. Glia 2:119128.

Parton RG. 1994. Ultrastructural localization of gangliosides; GM 1 is concentrated in caveolae. J Histochem Cytochem 42:155- 166.

Peden KWC, Charles C, Sanders L, Tennekoon GI. 1989. I solation of rat schwann cell lines: use of SV40 T antigen gene regulated by synthetic metallothionein promoters. Exp Cell Res 185:60-72.

Porter S, Clark MB, Glaser L, Bunge RP. 1986. Schwann cells stimulated to proliferate in the absence of neurons retain full functional capability. J Neurosci 6:3070-3078.

Reale E, Luciano L, Spitznas M. 1975. Freeze-fracture faces of the perineurial sheath of the rabbit sciatic nerve. J Neurocytol 4:261270

Ridley AJ , Davis J B, Stroobant P, Land H. 1989. Transforming growth factors-b1 and b2 are mitogens for rat Schwann cells. J Cell Biol 109:3419-3424.

Rothberg KG, Ying Y, Kamen BA, Anderson RGW. 1990. Cholesterol controls the clustering of the glycophospholipid-anchored membrane receptor for 5-methyltetrahydrofolate. J Cell Biol 111:29312938.

Rothberg KG, Heuser J E, Donzell WC, Ying Y, Glenney J R, Anderson RGW. 1992. Caveolin, a protein component of caveolae membrane coats. Cell 68:673-682.

Russell J W, Windebank AJ , Schenone A, Feldman EL. 1998. Insulinlike growth factor-I prevents apoptosis in neurons after nerve growth factor withdrawal.J Neurobiol 36:455-467.

Sandri C, Van Buren J M, Akert K. 1977. Mesenchymal structures in the nervous system. In: Membrane morphology of the vertebrate nervous system. Amsterdam: Elsevier. p 325-361.

Sargiacomo M, Sudol M, Tang Z-L, Lisanti MP. 1993. Signal transducing molecules and glycosyl-phosphatidylinositol-lined proteins form a caveolin-rich insoluble complex in MDCK cells. J Cell Biol 122:789-807.

Sargiacomo M, Scherer PE, Tang Z, Kubler E, Song KS, Sanders MC, Lisanti MP. 1995. Oligomeric structure of caveolin: implications for caveolae membrane organization. Proc Natl Acad Sci USA 92:94079411.

Sasagasako N, Toda K, Hollis M, Quarles RH. 1996. Myelin gene expression in immortalized Schwann cells: relationship to cel density and proliferation. J Neurochem 66:1432-1439.

Scheiffele P, Verkade P, Fra AM, Virta H, Simons K, I konen E. 1998. Caveolin- 1 and -2 in the exocytic pathway of MDCK cells.J Cell Biol 140:795-806.

Scherer PE, Lisanti MP, Baldini G, Sargiacomo M, Corley Mastick C, Lodish HF. 1994. Induction of caveolin during adipogenesis and association of GLUT4 with caveolin-rich vesicles. J Cell Biol 127: $1233-1243$.

Scherer PE, Tang Z, Chun M, Sargiacomo M, Lodish HF, Lisanti MP. 1995. Caveolin isoforms differ in their N-terminal protein sequence and subcellular distribution.J Biol Chem 270:16395-16401.

Scherer PE, Okamoto T, Chun M, Nishimoto I, Lodish HF, Lisanti MP. 1996. Identification, sequence, and expression of caveolin-2 defines a caveolin gene family. Proc Natl Acad Sci USA 93:131-135.

Scherer SS, Asbury AK. 1993. Inherited axonal neuropathies. In: Rosenberg RN, Prusiner SB, DiMauro S, Barchi RL, Kunkle LM editors. The molecular and genetic basis of neurological disease. Butterworth-Heinemann. p 899-921.

Scherer SS, Salzer J L. 1996. Axon-Schwann cell interactions during peripheral nerve degeneration and regeneration. In: J essen $K R$, Richardson WD, editors. Glial cell development. Oxford, UK: BIOS Scientific Publishers Limited. p 165-196.

Scherer SS, Deschenes SM, Xu Y, Grinspan J B, Fischbeck KH, Paul DL. 1995. Connexin32 is a myelin-related protein in the PNS and CNS. J Neurosci 15:8281-8294. 
Schnitzer J E, Mcl ntosh DP, Dvorak AM, Liu J , Oh P. 1995. Separation of caveolae from associated microdomains of GPI-anchored proteins. Science 269:1435-1439.

Severs NJ . 1988. Caveolae: static inpocketings of the plasma membrane, dynamic vesicles or plain artifact? J Cell Sci 90:341-348.

Shaul PW, Smart EJ , Robinson LJ, German Z, Yuhanna IS, Ying Y, Anderson RGW, Michel, T. 1996. Acylation targets endothelial nitric-oxide synthase to plasmalemmal caveolae. J Biol Chem.271: 6518-6522.

Simionescu N. 1983. Cellular aspects of transcapillary exchange. Physiol Rev 63:1536-1571.

Simionescu N, Lupu F, Simionescu M. 1983. Rings of membrane sterols surround the openings of vesicles and fenestrae, in capillary endothelium. J Cell Biol 97:1592-1600.

Simons K, Wandinger-Ness A. 1990. Polarized sorting in epithelia. Cell 62:207-210.

Smart EJ, Ying Y-S, Mineo C, Anderson RGW. 1995. A detergent-free method for purifying caveolae membrane from tissue culture cells. Proc Natl Acad Sci USA 92:10104-10108.

Song KS, Li S, Okamoto T, Quilliam LA, Sargiacomo M, Lisanti MP. 1996a. Co-purification and direct interaction of Ras with caveolin an integral membrane protein of caveolae microdomains. J Biol Chem 271:9690-9697.

Song KS, Scherer PE, Tang Z, Okamoto T, Li S, Chafel M, Chu C, Kohtz DS, Lisanti MP. 1996b. Expression of caveolin-3 in skeletal, cardiac, and smooth muscle cells. J Biol Chem 271:15160-15165.

Stewart HJ S, Mirsky R, J essen KR. 1996. The Schwann cell lineage: embryonic and early postnatal development. In: J essen KR, Richardson WD, editors. Glial cell development. Oxford, UK: BIOS Scientific Publishers Limited. p 1-30.

Syroid DE, Maycox PR, Burrola PG, Liu NL, Wen DZ, Lee KF, Lemke G, Kilpatrick TJ . 1996. Cell death in the Schwann cell lineage and its regulation by neuregulin. Proc Natl Acad Sci USA 93:9229-9234.

Tang Z, Scherer PE, Okamoto T, Song K, Chu C, Kohtz DS, Nishimoto I, Lodish HF, Lisanti MP. 1996. Molecular cloning of caveolin-3, a novel member of the caveolin gene family expressed predominantly in muscle. J Biol Chem 271:2255-2261.

Uittenbogaard A, Ying Y, Smart EJ. 1998. Characterization of a cytosolic heat-shock protein-caveolin chaperone complex. J Biol Chem 273:6525-6532.

Umemori H, Sato S, Yagi T, Aizawa S, Yamamoto T. 1994. Initial events of myelination involveF yn tyrosine kinase signalling. Nature 367:572-576.

Verity AN, Bredesen D, Vonderscher C, Handley VW, Campagnoni AT. 1993. Expression of myelin protein genes and other myelin components in an oligodendrocytic cell line conditionally immortalized with a temperature-sensitive retrovirus. J Neurochem 60:577-587.

Waggener J D, Bunns SM, Beggs J. 1965. The diffusion of ferritin within the peripheral nerve sheath: an electron microscopic study. J Neuropathol Exp Neurol 24:430-443.

Wary KK, MainieroF, I sakoff SJ , MarcantonioEE, Giancotti FG. 1996. The adapter protein Shc couples a class of integrins to the control of cell cycle progression. Cell 87:733-743.

Wary KK, Mariotti A, Zurzolo C, Giancotti FG. 1998. A requirement for caveolin-1 and associated kinase Fyn in integrin signaling and anchorage-dependent cell growth. Cell 94:625-634.

Webster H. 1993. Development of peripheral nerve fibers. In: Dyck PJ Thomas PK, Griffin J W, Low PA, Podulso J F, editors. Peripheral neuropathy. Philadel phia: Saunders. p 243-266.

Wood PM, Schachner M, Bunge RP. 1990. Inhibition of Schwann cell myelination in vitro by antibody to the L1 adhesion molecule. J Neurosci 10:3635-3645.

Wu C, Butz S, Ying Y, Anderson RGW. 1997. Tyrosine kinase receptors concentrated in caveolae-like domains from neuronal plasma membrane. J Biol Chem 272:3554-3559.

Yamamoto M, Toya Y, Schwencke C, Lisanti MP, Myers J r MG, Ishikawa Y. 1998. Caveolin is an activator of insulin receptor signaling. J Biol Chem 273:26962-26968. 